\title{
Understanding Implementation of Basel II and III in Albania: Obstacles and Solutions
}

\section{Sokol Ndoka}

PHD Cand. , European University of Tirana, Tirana, Albania

Altin Zefi

PHD. Cand. , European University of Tirana, Tirana, Albania

Ermela Kripa

Prof. Assoc. Dr , European University of Tirana, Tirana, Albania

\section{Abstract}

Banking Sector in Albania is suffering from high NPL levels, compared with historic levels of NPL in Albania, or with regional nations who have comparable economics. The 2008 crises in USA taught us the impact that the real economy can have from a crisis in Banking Sector. Thus the implementation of Basel III framework and its Capital Requirement ratios becomes crucially important for the stability of the Financial sector and stable growth of the economy. This paper firstly examines the state of Basel II implementation in Albania by the banking sector. The banking sector is primarily invested in government bonds and treasuries and lending to businesses and individuals but the high levels of NPL from both bankrupted businesses and individual poses a credit risks and wider market risks. Albanian Government has committed to speed up implementation of Basel II and Basel III on capital ratios. But questions remain: What's the status of the implementation? Can the economy absorb the costs of implementing or not implementing Basel III? Secondly we research the additional costs associated with implementation of the banking sector. Because of the expansionary policy of the Bank of Albania the lending rates have fallen but not as fast as expected. Credit growth has been mostly stagnant posing a risk to the growth of the economy. For this study we use time series on Financial Institutions in Albania from the Bank of Albania on capital ratios as well as the policies and requirements set. We find that Basel II criteria have not been met and more can be done to prepare the implementation of Basel III.

Keywords: Basel II, Basel III, Bank of Albania, Banking Sector, Implementation, Capital Requirements

\section{Introduction}

Financial sector is crucial to the development of the real economy, production and the transfer of the means of the production from the owner to entrepreneurs. But the financial sector also poses huge risks to the real economy. The 2008 sub-prime mortgage crises in the USA came to be known as the "Great Recession" a term reminiscent of the Great Depression of the 1930s.

Albanian banking sector has been exposed to some of the same risks as its counterpart in the west. The NPL reached new levels risking to drag down the real economy. The causes of these NPL levels, which in September 2014 reached the level of $24,9 \%$, are identified in the study of Meka.

Lack of economic growth

Declining remittances from emigrants

Unpaid and deferred government obligations to businesses

Loan making patterns applied by Albanian banks before and after the crises

Chart 1: Source: International Monetary Fund, Global Financial Stability Report 


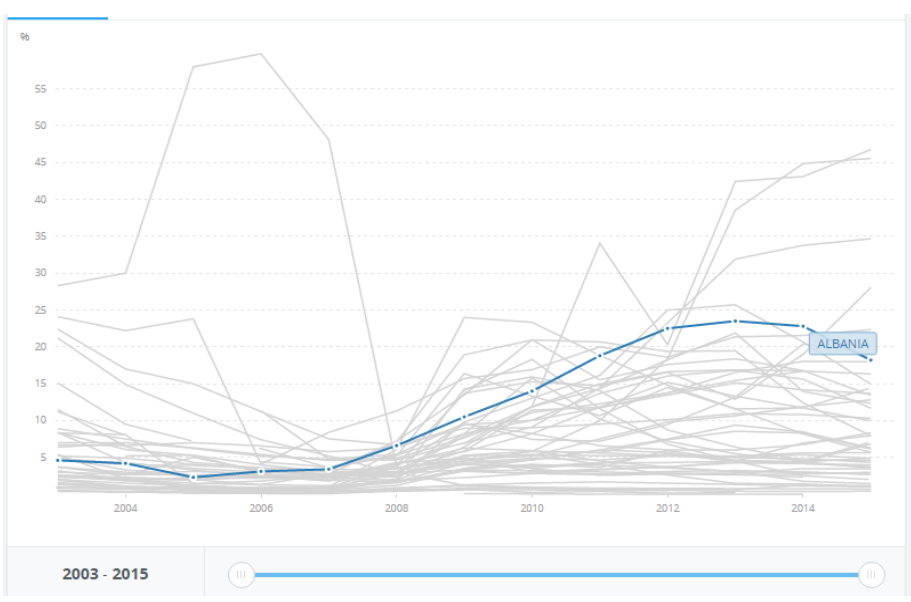

In 2015 NPL in Albania 18.2\% with an improving trend after the write-offs from the balance sheet of the banks. Countries in the region with a NPL worse than Albania is Serbia and Greece. We would expect Greece to be in this level due to the financial crises that Greece is going through but why Serbia since they are ahead of all regional countries (list below) in implementing Basel II requirements?

According to the National Bank of Serbia the main cause is the risk coming from exchange rate (National Bank of Serbia 2012). About $75 \%$ of the loans are denominated in Euro and $90 \%$ of the savings are also in foreign currency, mostly Euro.

Despite the small improvements NPL in Albania remain at high levels and more should be done to improve the situation.

\section{Basel II}

Basel Committee was created in 1974 in response to the Bretton Woods system collapse to respond to the need for the oversight of the banking system. Out of the committee came the 1988 Accord, subsequently called the Basel I and after much critique (see Jones, 2000) was improved in its final version produced in 2006: "Basel II: International Convergence of Capital Measurement and Capital Standards: A Revised Framework - Comprehensive Version". The summery of Basel II is presented by Caruana (2004) in the chart below:

\section{Pillars of Basel II}

\begin{tabular}{|c|c|c|}
\hline Pillar 1 & Pillar 2 & Pillar 3 \\
\hline $\begin{array}{l}\text { Minimum Capital Requirements: } \\
\text { - Risk management incentives } \\
\text { - New operational risk capital } \\
\text { charge } \\
\text { - Risk weighted assets (RWA) for } \\
\text { credit more risk sensitive } \\
\text { - Market risk largely unchanged }\end{array}$ & $\begin{array}{l}\text { Supervisory Review: } \\
\text { - Solvency reports } \\
\text { - Regulatory review } \\
\text { - Regital determination } \\
\text { - Addresses risks that are not } \\
\text { captured in Pillar } 1 \text { like } \\
\text { concentration, interest rate, and } \\
\text { liquidity risks }\end{array}$ & $\begin{array}{l}\text { Market Discipline: } \\
\text { - Minimum disclosure requirements } \\
\text { - Ccope } \\
\text { - Capital transparency } \\
\text { - Risk measurement \& management } \\
\text { - Risk profiling }\end{array}$ \\
\hline
\end{tabular}

Figure 1: 3 Pillars of Basel II

Source; Jaime Caruana, 2014

\section{1- Basel II accord and the its integration in the Albanian regulatory system}

The challenges for Albania in adopting Basel II standards were foreshadowed by then Governor of the BOA. Of the many challenges he foresees in the information disclosure criteria by the banks is the public reaction to bad news. 
"However, in short run information disclosure might also have some adverse implication, say in Albania. Let me explain myself better on this issue. Public is usually more sensitive to bad news than positive developments. In countries like Albania, reactions between good or bad news are even more asymmetric than in mature market economies. Public in Albania is particularly over-reactive toward grim news on banking sector or on a certain bank while tend to ignore what falls in the positive side. This could be due to both historical factors, e.g. the crisis of financial system in 1997, and culture factors e.g. low level of bank business understanding, e.g. the overreaction of public to the introduction of the Deposit Insurance Law in 2002. This means that enhanced information disclosure required by Basle II, could be problematic if not supported by a proper public understanding." (Fullani, 2005)

Mr. Fullani concludes by partially committing to try to implement Basel II "its implementation may be a bit too ambitious and a difficult task for our countries. Therefore, it is in our interest to find ways to make it more suitable to our needs by following a gradual approach rather than jeopardizing its success through an uninformed adoption." (Fullani, 2015)

Despite the reluctant beginning by Albania's regulatory body, BOA, the Basel II framework and its policy goals became a necessity since the EU has made compliance with Basel II mandatory for countries that opt to join EU.

In its medium term policy strategy, the governing body of the Bank of Albanian laid out the goals to implement the Basel II accord in the areas of Capital requirement, regulatory policy and adopting the IFRS accounting principles. (BoA - Strategjia Afatmesme e Zvhillimi 2013 - 2015). As a consequence, the Bank of Albania regulatory body released in 2013 the new policy: "The report on capital adequacy" and this report was followed with an update in 2014.

In a survey from FSI done in 2015 BOA indicated the following information:

\section{Section One: Survey responses on Basel II implementation}

\begin{tabular}{|c|c|c|c|c|}
\hline Country & Elements $^{1}$ & Status $^{2}$ & Year $^{3}$ & Remarks \\
\hline \multirow[t]{10}{*}{ Albania } & SA & 4 & 2014 & \multirow{10}{*}{$\begin{array}{l}\text { Pillar 3: Regulation "On minimum requirements for } \\
\text { disclosure of information by banks and branches of } \\
\text { foreign banks" was amended in the beginning of } 2015 \text {, } \\
\text { aiming the review of the regulatory framework in order to } \\
\text { increase transparency and promote banking market } \\
\text { discipline, through the alignment with the European } \\
\text { directives and regulations on the activities of credit } \\
\text { institutions and the Basel Committee standards for } \\
\text { disclosure of information. }\end{array}$} \\
\hline & FIRB & 1 & NA & \\
\hline & AIRB & 1 & NA & \\
\hline & $\mathrm{BIA}$ & 4 & 2014 & \\
\hline & TSA & 4 & 2014 & \\
\hline & AMA & 1 & NA & \\
\hline & SMM & 4 & 2014 & \\
\hline & IM & 1 & NA & \\
\hline & P2 & 1 & 2015 & \\
\hline & P3 & 4 & 2015 & \\
\hline
\end{tabular}

Figure 2: Basel II implementation

1 The following abbreviations are used in the table: Pillar $1-$ credit risk: $S A=$ standardised approach, FIRB = foundation internal ratings-based approach, $\mathrm{AIRB}=$ advanced internal ratings-based approach; Pillar 1 - operational risk: $\mathrm{BIA}=$ basic indicator approach, TSA = standardised/alternative standardised approach, AMA = advanced measurement approaches; Pillar 1 - market risk: SMM = standardised measurement method, IM = internal models; P2 = Pillar 2; P3 = Pillar 3

Status indicators are as follows: 1 = draft regulation not published, 2 = draft regulation published, 3 = final rule published, $4=$ final rule in force, $5=$ not applicable.

3 This column denotes the year in which the draft or final rule was or is expected to be published or when the final rule was or will be in force. NA means that the jurisdiction is not planning to implement this component or is planning to implement the component but does not know the year in which it will be implemented.

\section{Source: BIS survey by FSI, 2015}

Table 1 : Albania's Compliance with Basel II relative to regional countries

\begin{tabular}{|l|l|l|l|l|l|l|}
\hline Elements1 & Albania & $\begin{array}{l}\text { Bosnia and } \\
\text { Herzegovina }\end{array}$ & Montenegro & Macedonia & Kosovo & Serbia \\
\hline
\end{tabular}




\begin{tabular}{|l|l|l|l|l|l|l|l|l|l|l|l|l|}
\hline SA & 4 & 2014 & 1 & 2016 & 4 & 2008 & 4 & 2012 & 4 & 2013 & 4 & 31. Dec.11 \\
\hline FIRB & 1 & NA & 1 & 2016 & 1 & 2015 & 1 & 2016 & 5 & NA & 4 & 31 .Dec.11 \\
\hline AIRB & 1 & NA & 1 & 2016 & 1 & 2015 & 1 & 2016 & 5 & NA & 4 & 31. Dec.11 \\
\hline BIA & 4 & 2014 & 4 & 2009 & 4 & 2008 & 4 & 2012 & 4 & 2013 & 4 & 31. Dec.11 \\
\hline TSA & 4 & 2014 & 1 & 2016 & 4 & 2008 & 4 & 2012 & 4 & 2013 & 4 & 31. Dec.11 \\
\hline AMA & 1 & NA & 1 & 2016 & 1 & 2015 & 1 & 2016 & 5 & NA & 4 & 31. Dec.11 \\
\hline SMM & 4 & 2014 & 1 & 2016 & & & 4 & 2009 & 1 & NA & 4 & 31. Dec.11 \\
\hline IM & 1 & NA & 1 & 2016 & & & 1 & 2016 & 5 & NA & 4 & 31. Dec.11 \\
\hline P2 & 1 & 2015 & 1 & 2016 & 4 & 2012 & 4 & 2009 & 4 & $\begin{array}{l}2013 \\
\text { partially }\end{array}$ & 4 & 31. Dec.11 \\
\hline P3 & 4 & 2015 & 1 & 2016 & 4 & 2012 & 4 & 2007 & 4 & $\begin{array}{l}2013 \\
\text { partially }\end{array}$ & 4 & 31.Dec.11 \\
\hline
\end{tabular}

1 The following abbreviations are used in the table: Pillar 1 - credit risk: SA = standardised approach, FIRB = foundation internal ratings-based approach, $\mathrm{AIRB}=$ advanced internal ratings-based approach; Pillar 1 - operational risk: $\mathrm{BIA}=$ basic indicator approach, TSA = standardised/alternative standardised approach, AMA = advanced measurement approaches;

Pillar 1 - market risk: SMM = standardised measurement method, IM = internal models; P2 = Pillar 2; P3 = Pillar 3

Status indicators are as follows: 1 = draft regulation not published, 2 = draft regulation published, $3=$ final rule published, $4=$ final rule in force, $5=$ not applicable.

\section{Source: BIS, 2015}

As seen in the table above Albanian has done progress in most indicators of Basel II. BOA chose to apply the Standard Approach (SA) in Credit Risk evaluation. Progress has been made in Pillar III with the 2008 "On minimum requirements of disclosing information from banks and foreign bank branches" and the updated 2014 version.

\section{Basel III}

Little to no progress has been made in adopting the Basel III. bankruptcy of Lehman Brothers increased the urgency to improve on the Basel II framework. According to the BIS (BIS, 2015) "banks were operating with high leverage and inadequate liquidity buffers" (BIS, 2015)

Table 2 : Section Three: Survey responses on Basel III implementation

\begin{tabular}{|c|c|c|c|c|c|c|c|c|c|c|c|c|}
\hline \multirow{3}{*}{$\begin{array}{l}\text { Liq } \\
\text { (LCR) } \\
\text { Def cap }\end{array}$} & \multicolumn{2}{|c|}{ Albania } & & & \multicolumn{4}{|c|}{ Bosnia and Herzegovina } & \multicolumn{2}{|c|}{ Montenegro } & \multicolumn{2}{|c|}{ Macedonia } \\
\hline & \multicolumn{2}{|l|}{1} & \multicolumn{2}{|c|}{2016} & \multicolumn{2}{|l|}{1} & \multicolumn{2}{|c|}{2016} & \multicolumn{2}{|l|}{1} & \multicolumn{2}{|c|}{2016} \\
\hline & 4 & 2015 & 1 & 2016 & 1 & 2016 & 4 & 2012 & 5 & 2016 & 1 & 31.12 .2015 \\
\hline $\begin{array}{l}\text { Risk } \\
\text { cov }\end{array}$ & 1 & $\begin{array}{l}2016- \\
2017 \\
\end{array}$ & 1 & 2016 & 1 & 2016 & 1 & 2016 & 5 & NA & 1 & 31.12 .2015 \\
\hline Conserv & 1 & $\begin{array}{l}2016- \\
2017\end{array}$ & 2 & 2016 & 1 & 2016 & 1 & 2015 & 5 & 2018 & 4 & 31.Dec.11 \\
\hline C-cycl & 1 & $\begin{array}{l}2016- \\
2017\end{array}$ & 2 & 2016 & 1 & 2016 & 1 & 2015 & 5 & 2018 & 1 & 31.12 .2015 \\
\hline LR & 1 & $\begin{array}{l}2016- \\
2017\end{array}$ & 2 & 2015 & 1 & 2016 & 1 & 2015 & 5 & 2016 & 1 & 31.12 .2015 \\
\hline D-SIBs & 1 & $\begin{array}{l}2016- \\
2017\end{array}$ & 2 & 2016 & 1 & 2016 & 1 & 2015 & 5 & NA & 1 & 31.12 .2015 \\
\hline G-SIBs & 1 & $\begin{array}{l}2016- \\
2017 \\
\end{array}$ & 5 & NA & 1 & 2016 & 5 & NA & 5 & NA & 1 & 31.12 .2015 \\
\hline
\end{tabular}

The following abbreviations are used in the table: Liq = liquidity standard; Def cap = definition of capital; Risk cov = risk coverage; Conserv = capital conservation buffer; $\mathrm{C}$-cycl = countercyclical capital buffer; $\mathrm{LR}=$ leverage ratio. 
1 Status indicators are as follows: 1 = draft regulation not published; 2 = draft regulation published; 3 = final rule published; $4=$ final rule in force; $5=$ not applicable.

\section{BIS: Survey of FSI, 2015.}

In a survey by FSI (Financial Stability Institution) it was reported that:" The Supervision Department of the Bank of Albania has already begun its preparatory work for moving toward Basel III. By the beginning of 2015 BoA has started an impact study with the banking sector for assessing the level of LCR in the Albanian banking system." (FSI, 2015)

The is no report of progress done on implementing Basel III requirements. Should there be one? According to studies (see Civici, 2012) the cost of implementing Basel III is $0.15 \%$ of GDP.

\section{Compliance of Albanian banking institutions with the BoA requirements}

BOA needs to do more to formalize the ICAAP and according to reports it working with the bank of Italy. At this time there is no concern for banks to meet the requirements for the level of capital due to the weak investments by the economy. In the future Pillar 2 of Basel Acord should be formalized and procedures be formulated in accordance with EU guidelines for Banking Oversight.

\section{The cost benefit of Basel III}

As banks in the developing countries strive to implement Basel II it has become a fact that banks in the developed world have already complied with capital requirements of Basel III. Basel III strives to improve on banks' ability to absorb loses by increasing capital requirements, especially the Common Equity Tier 1 capital.

Mr. Stefan Ingves, Governor of the Sveriges Riksbank and Chairman of

the Basel Committee on Banking Supervision seems to be very excited to announce, in his 2013 speech that the banks have already complied with Basel III requirements. He states as follows:

"The good news is that the global banking industry is responding well to the new requirements and, for large parts of the industry, the transitional time may not be needed. For the 101 large internationally active banks (the so-called Group 1 banks) 1 that we survey every six months, the story is one of an industry that already on average meets the 2019 requirements. The average CET1 ratio at end-December 2012 was $9.2 \%$, well above the basic $7 \%$ minimum".(S. Ingves, 2013)

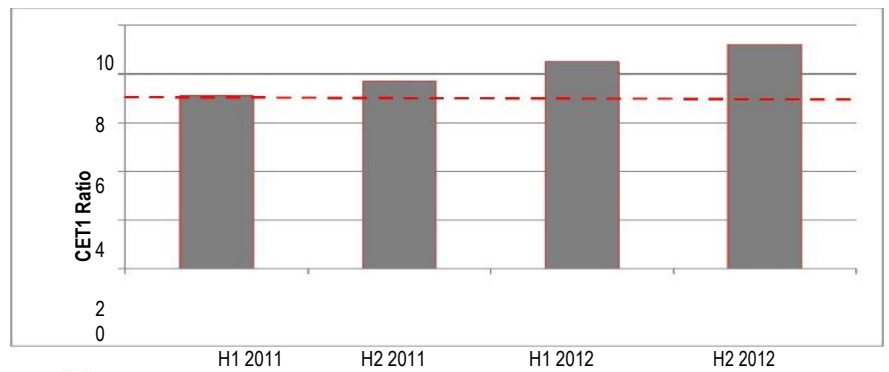

Basel III fully phased-in

Chart 2: CET1 Capital Ratio (\%), Group 1 banks

Source: Ingves, 2013

But should Mr. Ingves be so enthusiastic? Is it that large banks have complied with Basel III because of wanting to meet the standards? Implementation Basel III is associated with costs because higher ratios of capital must be kept by the banks. In capitalistic terms this doesn't make sense since banks would be affording unnecessary costs by tying up capital when they are not required. 
The reason the banks have extra capital is the Europe-wide consumption crises that has forced many European banks to resort to negative interest rates as explained by Ruchir Agarwal and Miles Kimball 2015. The same point is made by Randow and Kennedy, (Jana Randow \& Simon Kennedy 2016 "Negative interest rates are an act of desperation, a signal that traditional policy options have proved ineffective and new limits need to be explored. They punish banks that hoard cash instead of extending loans."

\section{Conclusions}

Albanian banking system is healthy despite the high level of NPL and the regional and national financial crises. Banks are profitable in spite of the lowering of crediting of the economy. The capital ratios to credit are above the levels as outlined in the Basel I because of the low crediting.

BoA has adopted regulation on Pillar 1 and Pillar 3 of Basel II requirements. In Pillar BoA has chosen to adopt the SA (Standard Approach) to measuring risk and capital requirements. This is because of the size of the banks. No rating companies have been approved in Albania and receiving ratings from foreign rating companies is expensive. Because of this choice the bank has ignored FIRB and AIRB indicators.

Some studies suggest that there is a negative relationship between CAR and NPL and bank profit. We noticed that in spite the fact that Serbia has implemented Basel II requirements since 2011 the NPL is among the highest in the region. Studding this relationship, it difficult because more time is needed to see the effects.

The BoA should do more to adopt the requirements and the procedures described in the Pillar II of Basel II on procedures to assessing banks' capital adequacy to their risk profile and strategies to managing this risk. European Union has issued guidelines which should be followed.

Despite the fact that the bank has done no effort in implementing Basel III the CAR is already above the required ratio of $7 \%$. Studies suggest that implementing Basel III may cost a national economy up to $0.15 \%$ of its GDP. Other studies should focus on the feasibility of implanting these standards and long term benefits.

\section{References}

[1] A.Fullani, 2005, "Basel II, its implications, opportunities and challenges ahead for Albania and Southeastern Europe", Southeastern European Financial Forum, the Second Edition, Bucharest, Romania, 11 November.

[2] BoA - Strategjia Afatmesme e Zvhillimi 2013 - 2015.

[3] K.Kodra, FCCA, D.Salko, Capital Adequacy In The Albanian Banking System; An Econometrical Analysis With A Focus On Credit Risk MrHead of Department of Finance and Accounting.

[4] FSI Survey Basel II, 2.5 and III Implementation July 2015.

[5] National Bank of Serbia, 2012.

[6] J.Randow \& S.Kennedy 2016 Negative Interest Rates, Less Than Zero Bloomberg Newspaper.

[7] S.Ingves, 2013: Ninth High Level Meeting for the Middle East \& North Africa Region. 